\title{
INFLUENCING STUDENTS TO JOIN THEIR AITP STUDENT CHAPTER
}

\author{
D. Scott Hunsinger, Appalachian State University, hunsingerds@appstate.edu \\ Michael B. Knight, University of Wisconsin-Green Bay, knightm@uwgb.edu \\ Jessica L. Russ, Appalachian State University, jr58078@appstate.edu
}

\begin{abstract}
The Association of Information Technology Professionals (AITP) is a professional organization that offers students, especially those majoring in Computer Information Systems (CIS) and related majors, a number of opportunities and benefits. We have discovered that a majority of CIS majors at our university, as well as other schools, have not joined their local AITP student chapter. To better understand why some students have not joined AITP, we first conducted interviews with CIS majors, both AITP members and non-AITP members, to elicit their perceptions and opinions about AITP. Based upon the findings from the interviews, we then surveyed 105 CIS students at our institution. We tested for significant differences between AITP members and non-AITP members. We discovered that some students have misperceptions about AITP. We also found that several factors, such as lack of time and money, may deter students from joining AITP. Some students have strong feelings, both positive and negative, about AITP. We used the Theory of Planned Behavior, along with Cognition and Affect constructs, to determine what factors significantly influence students' intentions to join or remain an AITP student member. As expected, Attitude and Perceived Behavioral Control significantly influence Intention. We also discovered that both Affect and Cognition are important predictors of Attitude. However, we were surprised to find that Subjective Norm does not significantly influence students' intentions. The model shows an impressive amount of variance explained for Behavioral Intention $\left(R^{2}=\right.$ .743). Our findings provide us evidence of which cognitive, affective, attitudinal, and control beliefs to target in order to better influence students to join their AITP student chapter.
\end{abstract}

Keywords: Professional Student Organizations, AITP, CIS Majors, Theory of Planned Behavior

\section{INTRODUCTION}

It seems intuitive that information systems majors

(IS, CIS, MIS, BIS, etc.) would join their respective Association of Information Technology Professionals
(AITP) student chapter, especially since AITP provides a number of opportunities and benefits to its members.

However, we were quite surprised to discover that a majority of the CIS majors at our university have not joined our AITP student chapter. After one of our co-authors (a former student in our CIS program) noticed that some of her CIS classmates did not attend our first AITP meeting in the Spring 2007 semester, she asked me (the AITP Faculty Advisor at our university) for more details about our club.

We discovered that only $28 \%$ (62 out of 220 ) of the CIS majors at our university had joined AITP after the second week of classes in Spring 2007. Hoping that this was an isolated incident, we gathered information about other AITP student chapters in our area. Unfortunately, we found that other schools also have a relatively low percentage of CIS majors who have joined AITP.

The mission of AITP is to offer opportunities for Information Technology (IT) leadership and education through partnerships with industry, government and academia. AITP provides quality IT related education, information on relevant IT issues, and forums for networking with experienced peers and other IT professionals. AITP's vision is to be recognized as the Information Technology professional organization of choice for providing leadership opportunities, professional development and personal growth [1].

Our question is: If AITP provides all of these benefits for its members, why aren't more students, especially CIS majors, joining AITP, and how can we influence them to join? Since the number of CIS majors who are also AITP members is relatively low for our university and other schools in our area, we decided to try to find out what factors encourage or discourage students from joining their school's AITP chapter.

We started out by searching various research databases for reasons that college students join computer-related clubs or organizations. Unfortunately, we found little information on the 
topic, which led us to conduct interviews and survey our students concerning the factors that influence them to join or not join AITP.

\section{LITERATURE REVIEW}

A small set of widely applied theories is commonly used to investigate intentions and behaviors. These include the theory of reasoned action (TRA) [3] and the theory of planned behavior (TPB) [2].

\section{Theory of Reasoned Action}

The theory of reasoned action (TRA) was introduced in 1967 and underwent multiple modifications and tests [17] before reaching its current form. The TRA has been applied to analyze a variety of situations and behaviors. According to the TRA, an individual's performance of a specific behavior is determined by his or her behavioral intention to perform it, which is determined by the individual's attitude and the subjective norm about the behavior. Subjective norm refers to the person's perception of the social pressures associated with performing the behavior.

The usage of TRA is restricted to volitional behaviors, those in which a person can decide at will whether to perform or not perform them [26]. Performance of behaviors under incomplete volitional control may depend on availability of opportunities and resources, including time, money, skills, and others' cooperation [2].

\section{Theory of Planned Behavior}

The theory of planned behavior (TPB) is an extension of the TRA that includes an additional antecedent of intention: the degree of perceived behavioral control [2]. Perceived behavioral control (PBC) refers to a person's perceptions of " $\ldots$ the presence or absence of requisite resources and opportunities" [5]. It is derived from Bandura's [8] concept of self-efficacy "the conviction that one can successfully execute (a given) behavior" [16].

In the TPB, behavioral intention is the weighted sum of attitude, subjective norms, and PBC. Behavior is the weighted sum of intention and PBC. TPB has been used in many studies to predict intention and behavior $[2,6,20,29]$.

Measures of PBC have often been found to improve prediction of behavior above and beyond attitude and subjective norm [4]. Meta-analyses have discovered that, on average, PBC explains a significant increase of an additional two percent of the variance in behavior and an additional six percent of the variance in intentions $[4,7]$.

\section{Affect and Cognition}

Attitude may be better explained if we consider it as having two aspects: Affective, or emotional, and cognitive, or outcome beliefs $[4,21,22,23,31]$. "It has been found that individuals differ in their reliance on Cognition versus Affect as determinants of Attitude and that the two components also take on different degrees of importance for different attitude objects" [4]. This study separates affective evaluations from outcome beliefs as suggested by Manstead and Parker [22].

\section{HYPOTHESES}

The TPB holds that a person's intention to perform the behavior in question is stronger when Attitude and Subjective Norm are more favorable and Perceived Behavioral Control is greater [15].

- Hypothesis 1: Attitude is significantly and positively related to intent to join or remain a member of AITP.

- Hypothesis 2: Subjective Norm is significantly and positively related to intent to join or remain a member of AITP.

- Hypothesis 3: Perceived Behavioral Control is significantly and positively related to intent to join or remain a member of AITP.

Previous studies on Affect and Cognition have found that they are positively related to attitude [21].

- Hypothesis 4: Cognition is significantly and positively related to Attitude regarding AITP.

- Hypothesis 5: Affect is significantly and positively related to Attitude regarding AITP.

\section{METHODOLOGY}

In order to begin conducting our research on how to encourage more CIS majors to join AITP, we first interviewed some of our students. One of our coauthors, a former student at our institution, randomly selected ten CIS majors and asked each of them 
thirteen questions concerning their thoughts about AITP. She interviewed both CIS majors who are currently members of AITP, as well as CIS majors who have not joined AITP. The thirteen questions were geared towards finding out more information on what students think about AITP and to elicit suggestions on how to improve AITP to encourage more non-members to join. We used the theory of planned behavior [2] to guide our interview questions.

Using structured interviews, we asked questions to investigate CIS majors' beliefs, thoughts, and attitudes about our AITP student chapter. All interviews were audio-taped and transcribed to ensure that we properly recorded each student's responses. We categorized the responses for each question to allow us to determine the most popular answers for each. We used thematic analysis (a process for encoding qualitative data) [9], going back through the data repeatedly to identify patterns among the students' responses.

Based upon the findings from the interviews, we created an online survey using SurveyMonkey (www.surveymonkey.com). We integrated the findings from the interviews with the theory of planned behavior constructs (Attitude, Subjective Norm, and Perceived Behavioral Control) to begin empirically analyzing CIS majors' intentions to become or remain an AITP member.

\section{Measures}

We measured three constructs directly using items validated in other research: Behavioral Intention, Attitude, and Affect. Other constructs were measured using items we developed from interviews with students.

\section{Behavioral Intention}

Three previously validated items were used to measure each respondent's intention to join or remain a member of AITP $[2,3]$. Respondents rated each Behavioral Intention statement on a seven-point bipolar scale ranging from -3 (Strongly Disagree) to +3 (Strongly Agree).

\section{Direct Measure of Attitude}

We computed a direct measure of Attitude using three statements validated in previous TRA and TPB studies that were found to exhibit high internal consistency $[2,26]$.

\section{Normative Beliefs and Motivation to Comply (Subjective Norm)}

We identified referent groups through interviews with students. To measure normative beliefs, participants rated their agreement or disagreement with statements about the views of referent groups, such as the person's CIS professors and potential employers, using a seven-point scale ranging from Strongly Agree (+3) to Strongly Disagree (-3). We also asked respondents to rate their motivation to comply with the opinions of each referent group on a seven-point scale ranging from Very Undesirable (1) to Very Desirable (7). We calculated an indirect measure of Subjective Norm by multiplying each normative belief by the corresponding motivation to comply and summing the products.

\section{Perceived Control and Degree of Facilitation (Perceived Behavioral Control)}

We used several statements generated from the preliminary interviews to measure the strength of the respondent's control beliefs; related statements were used to compute the perceived degree of facilitation of these beliefs. Beliefs were rated on a scale ranging from Strongly Agree (+3) to Strongly Disagree (-3), while perceived degree of facilitation was ranked using values from 1 to 7 . We calculated Perceived Behavioral Control by multiplying each control belief by the corresponding perceived degree of facilitation and adding the products.

\section{Outcome Beliefs and Evaluations (Cognition)}

Outcome belief measures were based upon input from interviews with CIS majors. We asked survey respondents to rate statements on a seven-point scale ranging from Strongly Disagree (-3) to Strongly Agree $(+3)$. Participants also indicated the outcome evaluation for each statement on a Likert-type scale ranging from Very Undesirable (1) to Very Desirable (7). We computed the Cognition measure by multiplying the likelihood rating for each outcome by its outcome evaluation and summing the products.

\section{Affect}

We computed Affect using previously validated measures [13, 27]. Participants indicated responses on a scale ranging from 1 (Strongly Disagree) to 5 (Strongly Agree). 


\section{Population and Sample}

The population targeted in this study was undergraduate CIS students at our university. Fiftynine percent of the respondents were current members of AITP when they completed the survey, while $41 \%$ had not joined AITP. Seniors comprised $47 \%$ of the respondents, followed by juniors $(38 \%)$, sophomores (11\%), and freshmen (4\%).

We emailed 220 Computer Information Systems majors at our university, asking them to complete the online survey. To encourage them to participate, we informed them that we would randomly select three participants and present each of them a $\$ 10$ Staples gift card. One hundred five (105) students completed the survey, a response rate of $47.7 \%$.

\section{Reliability and Validity}

The Cronbach's alpha for each composite construct, illustrated in Table 1, exceeds the recommended cutoff value of 0.7 [25], indicating acceptable construct validity.

Table 1. Cronbach's Alpha for Constructs

\begin{tabular}{|l|c|}
\hline \multicolumn{1}{|c|}{ Construct (\# of items) } & Cronbach's Alpha \\
\hline Behavioral Intention (3) & .970 \\
\hline Attitude (3) & .954 \\
\hline Subjective Norm (5) & .881 \\
\hline $\begin{array}{l}\text { Perceived Behavioral } \\
\text { Control (3) }\end{array}$ & .827 \\
\hline Cognition (6) & .936 \\
\hline Affect (4) & .941 \\
\hline
\end{tabular}

Before analyzing the data, we verified the assumptions of normality, linearity, and independence.

Using SPSS 14.0, we computed the correlations, illustrated in Table 2, and tolerances (not shown) for each variable. Using cutoffs of .90 for correlations and .20 for tolerance [18], we determined that multicollinearity does not present a problem. All correlations in Table 2 are significant at the 0.01 level.

Table 2. Correlation Matrix

\begin{tabular}{|l|c|c|c|c|c|}
\hline & ATT & AFF & COG & SN & PBC \\
\hline INT & .850 & .813 & .701 & .596 & .688 \\
\hline ATT & & .775 & .822 & .688 & .692 \\
\hline
\end{tabular}

\begin{tabular}{|l|l|l|l|l|l|}
\hline AFF & & & .718 & .592 & .654 \\
\hline COG & & & & .697 & .618 \\
\hline SN & & & & & .645 \\
\hline
\end{tabular}

\section{FINDINGS}

\section{Hierarchical Regression Analysis}

We used hierarchical multiple regression to analyze the questionnaire responses. This technique has been used in a number of previous studies based on the Theory of Planned Behavior [11, 14, 19, 24, 30].

Burns and Grove [10] recommend the use of at least 30 subjects per independent variable in order to ensure that the ratio of subjects to independent variables is substantial. The model contains five independent variables (Affect, Cognition, Attitude, Subjective Norm, and Perceived Behavioral Control). The model is tested in two parts:

- Test 1 examines the influence of Attitude, Subjective Norm, and Perceived Behavioral Control on Behavioral Intention. The minimum sample size for Test 1 is 90 .

- Test 2 examines the influence of Cognition and Affect on the Attitude construct. The minimum sample size for Test 2 is 60 .

These sample sizes are comparable to those of other small-sample studies that use hierarchical multiple regression and the theory of planned behavior [12, 24].

Assumptions based on theory and research determine when terms should be entered into the model [28]. As each term (or terms) is entered, the change in $\mathrm{R}^{2}$ is calculated and we determine whether each change is significantly different from zero [28]. We follow the suggestion of Ajzen and Madden [5] regarding order of entry of variables in the TPB, beginning with Attitude, followed by Subjective Norm then Perceived Behavioral Control. Table 3 illustrates the results of the first regression, in which Behavioral Intention is the dependent variable.

Table 3. First Hierarchical Regression

\begin{tabular}{|l|l|c|c|c|c|}
\hline Step & $\begin{array}{c}\text { Independe } \\
\text { nt } \\
\text { Variable(s) }\end{array}$ & $\mathbf{R}^{\mathbf{2}}$ & $\begin{array}{c}\text { Chg. } \\
\text { in } \\
\mathbf{R}^{2}\end{array}$ & $\boldsymbol{\beta}$ & $\mathbf{p}$ \\
\hline 1 & Attitude & .723 & .723 & .850 & $* * *$ \\
\hline
\end{tabular}




\begin{tabular}{|l|l|l|l|l|l|}
\hline 2 & Attitude & .723 & .000 & .836 & $* * *$ \\
Subjective & & & .021 & n.s. \\
Norm & & & & \\
\hline 3 & $\begin{array}{l}\text { Attitude } \\
\text { Subjective }\end{array}$ & .743 & .020 & .739 & $* * *$ \\
& $\begin{array}{l}\text { Norm } \\
\text { Perceived } \\
\text { Behavioral } \\
\text { Control }\end{array}$ & & & & \\
& & & .045 & n.s. \\
\hline
\end{tabular}

$* * \mathrm{p}<.01 ; * * * \mathrm{p}<.001 ;$ n.s. $=$ not significant

Two of the three traditional TPB constructs are significant (Attitude and Perceived Behavioral Control), while Subjective Norm is not significant in predicting Intention. Overall, the model shows a fairly high amount of variance explained for Behavioral Intention $\left(\mathrm{R}^{2}=.743\right)$.

To examine the influences of Cognition and Affect on Attitude, we performed a second hierarchical regression analysis with Attitude as the dependent variable. The results are shown in Table 4.

Table 4. Second Hierarchical Regression

\begin{tabular}{|l|l|c|l|c|c|}
\hline Step & $\begin{array}{l}\text { Independent } \\
\text { Variable(s) }\end{array}$ & $\mathbf{R}^{\mathbf{2}}$ & $\begin{array}{c}\text { Chg. } \\
\text { in } \mathbf{R}^{\mathbf{2}}\end{array}$ & $\boldsymbol{\beta}$ & $\mathbf{p}$ \\
\hline 1 & Cognition & .676 & .676 & .822 & $* * *$ \\
\hline 2 & $\begin{array}{l}\text { Cognition } \\
\text { Affect }\end{array}$ & .747 & .071 & .548 & $* * *$ \\
& $* * * \mathrm{p}<.001$ & .382 & $* * *$ \\
\hline \multicolumn{7}{|c|}{} \\
\hline
\end{tabular}

As anticipated, both Affect and Cognition are significant and each adds to the predictive value of the model.

Based on these results, we state the following regarding the hypotheses:

Hypothesis 1, "Attitude is significantly and positively related to intent to join or remain a member of AITP," is supported. Attitude was entered first into the regression equation $(\beta=.850$, $p$ $<.001)$.

Hypothesis 2, "Subjective Norm is significantly and positively related to intent to join or remain a member of AITP," is NOT supported. Subjective Norm $(\beta=.021)$ did not contribute significantly to the equation.

Hypothesis 3, "Perceived Behavioral Control is significantly and positively related to intent to join or remain a member of AITP," is supported. Attitude ( $\beta$ $=.739 ; \mathrm{p}<.001)$ and Perceived Behavioral Control $(\beta=.205 ; \mathrm{p}<.01)$ are significant in the equation.

Hypothesis 4, "Cognition is significantly and positively related to Attitude regarding AITP," is supported. Cognition was entered first into the regression equation $(\beta=.822 ; \mathrm{p}<.001)$.

Hypothesis 5, "Affect is significantly and positively related to Attitude regarding AITP," is supported. Cognition $(\beta=.548 ; \mathrm{p}<.001)$ and Affect $(\beta=.382 ; \mathrm{p}$ $<.001)$ are both significant in the equation.

\section{Comparison of Findings Between AITP and Non- AITP Members}

\section{Overall Perceptions of AITP}

Most survey respondents, both members and nonmembers, held favorable perceptions about AITP. Table 5 shows the combined breakdown of students who strongly agreed, agreed, or somewhat agreed with the statements they were provided about their perceptions of AITP. Students were asked to rate each statement ranging from Strongly Agree (1) to Strongly Disagree (7). The bolded statements are the ones in which we found a significant difference in the perceptions of members versus non-members. Table 5 also shows the average response for each group for each statement, as well as the F-test statistic comparing the two groups, which was used to see whether a significant difference exists between the two groups. Each question in Table 5 was proceeded with, "In my opinion, becoming (or remaining) a member of the AITP student chapter...."

Table 5. Student perceptions of AITP

\begin{tabular}{|l|c|c|c|c|}
\hline Statement & $\begin{array}{c}\text { \% in } \\
\text { Agree- } \\
\text { ment }\end{array}$ & $\begin{array}{c}\text { AITP } \\
\text { Avg }\end{array}$ & $\begin{array}{c}\text { Non- } \\
\text { AITP } \\
\text { Avg }\end{array}$ & $\begin{array}{c}\text { F- } \\
\text { test }\end{array}$ \\
\hline $\begin{array}{l}\text { Would be } \\
\text { worthwhile to } \\
\text { me. }\end{array}$ & $88 \%$ & 1.58 & 2.13 & 0.08 \\
\hline $\begin{array}{l}\text { Would give } \\
\text { me more } \\
\text { opportunities } \\
\text { to network } \\
\text { with hiring } \\
\text { managers. }\end{array}$ & $92 \%$ & 1.54 & 2.04 & 0.28 \\
\hline $\begin{array}{l}\text { Would give } \\
\text { me greater } \\
\text { access to }\end{array}$ & $92 \%$ & 1.79 & 2.17 & 0.13 \\
\hline
\end{tabular}




\begin{tabular}{|l|l|l|l|l|}
\hline $\begin{array}{l}\text { guest } \\
\text { speakers. }\end{array}$ & & & & \\
\hline $\begin{array}{l}\text { Would } \\
\text { expose me to } \\
\text { employers. }\end{array}$ & $\mathbf{9 2 \%}$ & 1.63 & 2.21 & $\mathbf{0 . 0 4}$ \\
\hline $\begin{array}{l}\text { Would allow } \\
\text { me to save } \\
\text { money on } \\
\text { certification } \\
\text { exams. }\end{array}$ & $\mathbf{8 6 \%}$ & 1.29 & 2.08 & $\mathbf{0 . 0 0}$ \\
\hline $\begin{array}{l}\text { Would be } \\
\text { helpful for } \\
\text { my career. }\end{array}$ & $\mathbf{9 0 \%}$ & 1.54 & 2.08 & $\mathbf{0 . 0 1}$ \\
\hline
\end{tabular}

Influence of Others

Table 6 shows the combined breakdown of students who strongly agreed, agreed, or somewhat agreed with the statements they were provided about whether certain referent groups think they should join or remain a member of AITP. Students were asked to rate each statement ranging from Strongly Agree (1) to Strongly Disagree (7). The bolded statements are the ones in which we found a significant difference in the perceptions of members and non-members. Table 6 also shows the average response for both AITP members and non-AITP members, as well as the Ftest statistic from comparing the two groups. Each question in Table 6 was proceeded with, "

think I should become (or remain) a member of the AITP student chapter."

Table 6. Referent groups' opinions of AITP

\begin{tabular}{|l|c|c|c|c|}
\hline Statement & $\begin{array}{c}\text { \% in } \\
\text { Agree- } \\
\text { ment }\end{array}$ & $\begin{array}{c}\text { AITP } \\
\text { Avg }\end{array}$ & $\begin{array}{c}\text { Non- } \\
\text { AITP } \\
\text { Avg }\end{array}$ & F-test \\
\hline $\begin{array}{l}\text { My CIS } \\
\text { professors }\end{array}$ & $\mathbf{9 4 \%}$ & 1.38 & 1.71 & $\mathbf{0 . 0 5}$ \\
\hline $\begin{array}{l}\text { My } \\
\text { classmates / } \\
\text { friends }\end{array}$ & $56 \%$ & 2.33 & 3.33 & 0.59 \\
\hline My parents & $50 \%$ & 2.63 & 3.38 & 0.62 \\
\hline $\begin{array}{l}\text { Job } \\
\text { employers }\end{array}$ & $68 \%$ & 2.04 & 2.54 & 0.95 \\
\hline $\begin{array}{l}\text { Other people } \\
\text { important to } \\
\text { me }\end{array}$ & $42 \%$ & 2.54 & 3.25 & 0.71 \\
\hline
\end{tabular}

\section{Limiting Factors}

We found that there are three main limiting factors that may discourage students from joining AITP. The first limiting factor is time. Some students do not have enough free time to attend the meetings due to jobs, school, work, and other university activities such as clubs or sports. We also found that money is a limiting factor for students to join. The fees to join AITP at our university are \$20/semester or \$30/year. Some students stated that they do not have enough money to pay this fee, and can join other clubs for free or for a lower cost. In addition, some students do not possess enough knowledge about AITP to decide whether to join.

Table 7 shows the combined breakdown of students who agreed with the statements they were provided about whether certain limiting factors restrict them from joining or remaining a member of AITP. Students were asked to rate each statement ranging from Strongly Agree (1) to Strongly Disagree (7). We found a significant difference in the perceptions of members and non-members for all three statements. Table 7 also shows the average response for both AITP members and non-AITP members, as well as the F-test value. Each question in Table 7 was proceeded with, "I to become (or remain) a member of the AITP student chapter."

Table 7. Factors limiting students from joining AITP

\begin{tabular}{|l|c|c|c|c|}
\hline Statement & $\begin{array}{c}\text { \% in } \\
\text { Agree- } \\
\text { ment }\end{array}$ & $\begin{array}{c}\text { AITP } \\
\text { Avg }\end{array}$ & $\begin{array}{c}\text { Non- } \\
\text { AITP } \\
\text { Avg }\end{array}$ & F-test \\
\hline $\begin{array}{l}\text { Have the } \\
\text { time }\end{array}$ & $70 \%$ & 1.79 & 2.88 & $\mathbf{0 . 0 0}$ \\
\hline $\begin{array}{l}\text { Know } \\
\text { enough } \\
\text { about AITP } \\
\text { whether }\end{array}$ & $76 \%$ & 1.63 & 3.04 & $\mathbf{0 . 0 0}$ \\
\hline $\begin{array}{l}\text { Have the } \\
\text { money }\end{array}$ & $82 \%$ & 1.63 & 2.38 & $\mathbf{0 . 0 0}$ \\
\hline
\end{tabular}

\section{Feelings about AITP}

Table 8 shows the combined breakdown of students who agreed with the statements they were provided concerning their feelings about AITP. Students were asked to rate each statement ranging from Strongly Agree (1) to Strongly Disagree (7). We found a significant difference in the perceptions of members and non-members for all four statements. Table 8 also shows the average response for both AITP members and non-AITP members, as well as the Ftest statistic comparing the two groups.

Each question in Table 8 was proceeded with, "I would to become (or remain) a member 
of the AITP student chapter."

Table 8. Students' feelings about AITP

\begin{tabular}{|l|c|c|c|c|}
\hline Statement & $\begin{array}{c}\text { \% in } \\
\text { Agree- } \\
\text { ment }\end{array}$ & $\begin{array}{c}\text { AITP } \\
\text { Avg }\end{array}$ & $\begin{array}{c}\text { Non- } \\
\text { AITP } \\
\text { Avg }\end{array}$ & F-test \\
\hline $\begin{array}{l}\text { Be excited / } \\
\text { somewhat } \\
\text { excited }\end{array}$ & $82 \%$ & 1.38 & 1.88 & $\mathbf{0 . 0 3}$ \\
\hline $\begin{array}{l}\text { Be satisfied } \\
\text { / somewhat } \\
\text { satisfied }\end{array}$ & $86 \%$ & 1.17 & 1.71 & $\mathbf{0 . 0 0}$ \\
\hline $\begin{array}{l}\text { Be happy / } \\
\text { somewhat } \\
\text { happy }\end{array}$ & $84 \%$ & 1.21 & 1.63 & $\mathbf{0 . 0 3}$ \\
\hline $\begin{array}{l}\text { Like } \\
\text { somewhat } \\
\text { like }\end{array}$ & $86 \%$ & 1.08 & 1.67 & $\mathbf{0 . 0 0}$ \\
\hline
\end{tabular}

\section{DISCUSSION}

The model shows a substantial amount of variance explained for Behavioral Intention $\left(\mathrm{R}^{2}=.743\right)$, with both Attitude and Perceived Behavioral Control significantly influencing students' intentions to join or remain a member of their AITP student chapter.

We were surprised to find that the Subjective Norm construct is not significant as suggested by the Theory of Planned Behavior. Traditional referent groups, including students' parents, potential employers, and friends, do not significantly influence students' intentions to join or remain a member of their AITP student chapter. No significant differences were found between AITP members and non-members' opinions concerning the influence of classmates/friends, parents, job employers, or other people important to them. The only significant difference for referent groups between AITP members and non-members dealt with CIS professors' opinions.

Deeper analysis allowed us to discover that $89 \%$ of the students who attended the first AITP meeting in the Spring 2007 semester were encouraged to attend by one of three CIS professors, even though there are thirteen professors in our CIS department. This suggests to us that professors are actually quite influential in encouraging students to join AITP. Even though we asked all of our CIS professors to promote the first AITP meeting to their students, our findings suggest that most of the professors are not effectively marketing the club to our students. We need to consider other ways to inform these professors' classes about AITP if the professor does not effectively promote the club to his/her students. One possibility would be to ask permission for an AITP student officer to give a short presentation about the club in each of the professor's classes.

As we expected, the Attitude and Perceived Behavioral Control (PBC) constructs significantly influence Behavioral Intention. Our findings provide evidence that several limiting (PBC) factors may prevent non-members from joining AITP. We discovered significant differences between members and non-members for all three factors from the survey: lack of time $(p<.01)$, knowledge $(p<.01)$, and money $(\mathrm{p}<.01)$. These findings suggest that we need to schedule meetings so more students have time to attend. We must also better inform our CIS majors about AITP, and make sure that students are not deterred from joining the club because of moneyrelated issues. We suspect a linkage between students' lack of knowledge about AITP and our CIS professors' lack of effectiveness in promoting the club to their classes. Several students provided interesting quotes relating to their lack of knowledge about AITP:
"I had not even heard of AITP until I was asked to complete this survey."
"I'm a Senior CIS major. None of my CIS professors last year mentioned anything about AITP."

Both additional constructs added to the model, Affect and Cognition, significantly influence Attitude. These two constructs explain $74.7 \%$ of the variance in Attitude. We found significant differences in students' feelings about AITP. Current members are more excited $(\mathrm{p}<.05)$, satisfied $(\mathrm{p}<.01)$, and happy $(\mathrm{p}<.05)$ about AITP. They also like AITP significantly more than non-members $(\mathrm{p}<.01)$. We suspect that prospective members would possess more positive feelings about the club if they were better informed.

We discovered significant differences between the AITP members and non-AITP members for several beliefs / perceptions relating to Cognition. Members expressed stronger agreement that AITP would provide them exposure to employers $(\mathrm{p}<.05)$, save them money on certification exams $(p<.01)$, and help them for their careers $(\mathrm{p}<.01)$. The results suggest that non-members lack an understanding of the benefits of AITP membership in our student 
chapter. Even though our AITP chapter offers certification exam discounts and other benefits to members, it seems that non-members are not aware of these things.

Increasing membership in professional student organizations related to the information systems major, such as AITP, will hopefully allow us to retain more of our IS majors. In addition to retaining current majors, we suggest trying to recruit new IS majors and double-majors by marketing AITP and other IS-related organizations to students majoring in fields other than information systems. This may also help us to attract and retain more females in the IS major if our colleges offer related professional student organizations that are appealing to them. It is important to make sure that students, no matter what their current major or gender, are fully aware of the club's benefits. The effects of these efforts may expand beyond the student organization, positively impacting the perception of and enrollment in the IS major at the institution.

We plan to expand our study in the future by including more universities across the US, thus providing us a larger sample size in which we could use Structural Equation Modeling (SEM) to further analyze relationships among constructs. It will be interesting to find out whether Subjective Norm remains non-significant with a larger sample.

\section{CONCLUSION}

The results from our analysis provide insight of which factors influence students whether to join or remain a member of their AITP student chapter. Our findings provide us evidence of which cognitive, affective, attitudinal, and control beliefs to target in order to better influence students to join or remain a member of their AITP student chapter.

\section{REFERENCES}

1. "About AITP." June 2004. http://aitp.org/organization/about/mission/missio n.jsp

2. Ajzen, I. (1991) The Theory of Planned Behavior. Organizational Behavior and Human Decision Processes, 50, 179-211.

3. Ajzen, I., \& Fishbein, M. (1980) Understanding Attitudes and Predicting Social Behavior, Prentice-Hall, Englewood Cliffs, NJ.
4. Ajzen, I., \& Fishbein, M. (in press). The influence of attitudes on behavior. In $D$. Albarracin, B. T. Johnson \& M. P. Zanna (Eds.), Handbook of attitudes and attitude change: Basic principles. Mahwah, NJ: Erlbaum.

5. Ajzen, I. and Madden, T.J. (1986) Prediction of Goal-Directed Behavior: Attitudes, Intentions, and Perceived Behavioral Control. Journal of Experimental Social Psychology, 22, 453-474.

6. Armitage, C. J., \& Conner, M. (2000) Efficacy of the theory of planned behavior: a metaanalytic review. "Journal of Social Psychology".

7. Armitage, C. J., \& Conner. M. (2001) Efficacy of the theory of planned behavior: A metaanalytic review. "British Journal of Social Psychology", 40, 471-499.

8. Bandura, A. (1977). Self-efficacy: Toward a unifying theory of behavioral change. "Psychological Review", 84, 191-215.

9. Boyatzis, R. (1998) Transforming Qualitative Information: Thematic Analysis and Code Development. Thousand Oaks, CA: Sage.

10. Burns, N. and Grove, S.K. (2001) The practice of nursing research, W.B. Saunders Co., Philadelphia.

11. Chau and Hu P.J.-H. "Information Technology Acceptance by Individual Professionals: A Model Comparison Approach," Decision Sciences 32(4), 2001, pp. 699-719.

12. Christian, J. and Armitage, C.J. (2002) "Attitudes and intentions of homeless people toward service provision in South Wales," British Journal of Social Psychology 41(2), 2002, pp. 219-231.

13. Crites, S.L., Fabrigar, L.R. \& Petty, R.E. (1994) "Measuring the affective and cognitive properties of attitudes: Conceptual and methodological issues," Personality \& Social Psychology Bulletin (20), 619-634.

14. Davis, F.D., Bagozzi, R.P., and Warshaw P.R. (1989) "User Acceptance of Computer Technology: A Comparison of Two Theoretical Models," Management Science 35(8), 982-1003.

15. Davis, L.E., Ajzen, I., Saunders, J., \& Williams, T. (2002) "The Decision of African American Students to Complete High School: An Application of the Theory of Planned Behavior," Journal of Educational Psychology 94(4), 810819.

16. Eagly, A. H., \& Chaiken, S. (1993) The Psychology of Attitudes, Harcourt Brace Jovanovich College Publishers, Fort Worth, TX.

17. Fishbein, M., \& Ajzen, I. (1975) "Belief, attitude, intention, and behavior: An 
introduction to theory and research". Reading, MA: Addison-Wesley.

18. Garson, G.D. PA 765 Statnotes: An Online Textbook. 2005 [cited 2008 November 24]; http://www2.chass.ncsu.edu/garson/pa765/statno te.htm

19. Harrison, Mykytyn, \& Riem (1997) "Executive decisions about adoption of information technology in small business: Theory and empirical tests," Information Systems Research 8(2) 171-195.

20. Ingram, K. L., Cope, J. G., Harju, B. L. \& Wuensch, K. L. (2000). Applying to Graduate School: A Test of the Theory of Planned Behavior. "Journal of Social Behavior and Personality", 15(2), 215-225.

21. Lavine, H., Thomsen, C.J., Zanna, M.P., \& Borgida, E. (1998) "On the primacy of affect in the determination of attitudes and behavior: The moderating role of affective-cognitive ambivalence," Journal of Experimental Social Psychology (34), 398-421.

22. Manstead, A.S.R. \& Parker, D. (1995) "Evaluating and extending the theory of planned behaviour," In European Review of Social Psychology, W. Stroebe and M. Hewstone (eds.), 6, Wiley, Chicester, England, 69-95.

23. Morris, J.D., Woo, C., Geason, J.A., \& Kim, J. (2002) "The Power of Affect: Predicting Intention," Journal of Advertising Research 42(3), 7-17.

24. Morris, M.G. \& Venkatesh, V. (2000) "Age differences in technology adoption decisions: Implications for a changing workforce," Personnel Psychology (53), 375-403.

25. Santos, J.R. (1999) Cronbach's alpha: A tool for assessing the reliability of scales. Journal of Extension, 37(2).

26. Sheppard, B. H., J. Hartwick, \& P. R. Warshaw. (1988). The Theory of Reasoned Action: A Meta-Analysis of Past Research with Recommendations for Modifications and Future Research. "Journal of Consumer Research", 15, 325-343.

27. Simons, J. \& Carey, K.B. (1998) "A structural analysis of attitudes toward alcohol and marijuana use," Personality \& Social Psychology Bulletin 24(7), 727-736.

28. Stockburger (1998) "Multivariate Statistics: Concepts, Models, and Applications," (2007:December 22), 1998.

29. Sutton, S. (1998). Predicting and explaining intentions and behavior: How well are we doing? "Journal of Applied Social Psychology", 28(15), 1317-1338.

30. Venkatesh, V. (2001) "A Longitudinal Investigation of Personal Computers in Homes: Adoption Determinants and Emerging Challenges," MIS Quarterly 25(1), 71-102.

31. Verplanken, B., Hofstee, G., \& Janssen, H.J.W. (1998) "Accessibility of affective versus cognitive components of attitudes," European Journal of Social Psychology (28),23-35. 